however defined, is a monstrosity. And yet some concrete end we must have. Here it is: corresponding to the theoretical ideal of "creating logical dispositions the undeceptive character of which we may bring to consciousness at every step" is the "ethical ideal of the practical sphere, to create instinctive natures, dispositions and moral characters, the undeceptiveness of which, in so far as they do the right spontaneously, they make clear at every step."

Any criticism of this curious logical somersault into the crudest psychological intuitionism is here out of place. One may, however, be allowed to suggest that such a union of empty universals and instinctive natures, even if it does away with the reproach of unfruitfulness, is as likely as not to give birth, as in the past, to practical and moral monsters.

$$
\text { W. M. U. }
$$

\title{
ASTHETIC SENTIMENTALISM.
}

Le nouveau sentimentalisme esthétique. CH. Lalo. Revue Philosophique, November, 1908, pp. 441-476.

This article contains, first, an exposition of Einfühlung as an æsthetic doctrine and, second, a criticism of it from the intellectualistic standpoint. The 'new sentimentalism' is the revival of the doctrine that 'feeling is the organ of beauty, and the conception of Einfühlung is its central point.' The term Einfühlung is untranslatable, but the author gives as paraphrases 'a kind of sympathy,' 'a projection of the self into objects,' ' the objectification of our affective life,' 'the identification of subject and object through the feelings.' Lipps and Volkelt are foremost among its advocates, and Karl Groos, Konrad Lange, Jonas Cohn, Paul Stern, Witasek and Dessoir are also mentioned among its supporters. The author traces the history of the term and of the conception for which it stands. He discusses the relation of Einfühlung to sympathy, to 'interior imitation,' to organic sensation, to association, to symbolism, to affective life, and to intellectual activities; in these discussions his starting point is a doctrine of some supporters of the Einfühlung theory. Needless to say they do not always agree among themselves, but they have this in common that they attempt to make Einfühlung fundamental and to show that other theories are simply subordinate elements in their doctrine.

In his criticism of this doctrine, M. Lalo raises three questions: (1) Has the objectification of affective life a fundamental role in asthetics? (2) Has the Einfühlung conception a true explanatory value, or is it a confused notion? (3) Does its philosophical significance rest upon acceptable principles ? 
In other words, what is the asthetic, the psychological, the philosophical value of this form of the sentimentalism?

With regard to the first, he insists that, though it may be true that there is such an objectification of affective life, it is not an exclusive possession of the asthetic experience, since perhaps the best examples of it are to be found in the animal forms of pleasure and pain. Moreover, the intensity of the projection is not a measure of the zsthetic value of experience; witness the rustic's experiences in seeing a play. Once more, complete objectification and identification with all that is contained in a drama with its many diverse characters, or in a museum, is quite impossible, but still æsthetic pleasure may be present. Einfühlung is not a notion, he concludes, which is adequate to explain the æsthetic character of the facts.

The second question also he answers in the negative; the conception suggests problems but solves none; its advocates disagree among themselves and the conception itself is confused. It is " internal imitation with no model, a symbol representing nothing but him who thinks it, an exteriorization of our sensibilities which creates within us new sensibilities of which we were incapable without it, a height and depth of affective life which excludes the highest and deepest sensible impulsions," and so on. In short, M. Lalo regards the Einfühlung theory as the eternal ' je ne sais quoi' erected into a principle of explanation. He cites various distinctions made by its advocates which he regards as artificial and charges that the alleged irreducibility of Einfühlung is the pretext for a lazy philosophy, while its " obscurity, a convenient refuge for an art criticism too conscious of its weaknesses, is, for the psychologist, merely a sign of insufficient analysis, and, for the logician, of insufficient explanation."

Its philosophical value is, in his opinion, quite as small. "The philosopher can see in the Einfühlung only a first step towards mysticism, and the rejection of every possibility of rational and scientific explanation." Volkelt's contention for the irreducibility of certain mental factors involved in Einfühlung is the principal object of this criticism.

In the experience described as Einfühlung, states usually subjective are objectified. Ordinarily the objectification of mental states is determined by utilitarian conditions, but in this case it is the technique of an art which brings it about. So says our author, and he concludes that the object of study should be this technique and not an alleged irreducible feeling of personality objectified in the object. This last is, he holds, quite fruitless as a principle of explanation or description. Here speaks the author of $L^{\prime}$ Esthétique expérimentale contemporaine. 
$\mathrm{He}$ is from the beginning of the article obviously hostile to everything smacking of 'le sentimentalisme' and not less so if it chance to be 'le sentimentalisme allemand.' There is point in most of his criticisms, but exception might be taken to his practice of attacking the form of the doctrine held by Volkelt or some one else and seeming to regard the result as a victory over the doctrine generally. Its advocates do disagree, and there is still much vagueness and uncertainty about the meaning of the conception. If he means to say that its supporters have not yet shown that it is an adequate description and explanation of all the facts, most readers would agree. But is every form of subjectivism to be condemned? There would certainly seem to be room in æsthetics for a description of the æsthetic experience in terms which might not be further analyzable, and also for a thoroughgoing study of the technique of the arts as furnishing the objective conditions for this experience.

Col,umbia University. AdAm Leroy Jones.

\section{BOOKS RECEIVED FROM SEPTEMBER 5 TO OCTOBER 5 .}

Social Development and Education. M. V. O'SheA. Boston, New York, and Chicago, Houghton Mifflin Co., r909. Pp. xiv + $56 \mathrm{I} . \$ 2$.

Der Pragmatismus. Neue Bahnen in der Wissenschaftslehre des Auslands. Günther JAcoBy. Leipzig, Dürr, 1909. Mk. 1.20. An Experimental Investigation into the Space Co-ordination of Different Senses. Charles B. McMulden. (Thesis.) Princeton, 1909. Pp. 28.

A Text-book of Psychology. Part I. Edward Bradford Titchener. New York, Macmillan Co., Ig09. Pp. xvi +302. \$r.3o net.

Beiträge zur Analyse der Gesichtswarnehmung. (Psychologische Studien. I. Abt.) F. SchUmanN, Editor. Leipzig, Barth, I909. Pp. 194. 6 Mark.

Outlines of Psychiatry. William A. White, M.D. $2 \mathrm{~d}$ ed. New York, Jr. Nervous and Mental Disease Publishing Co., I909. Pp. vi +232.

The New Schaf-Herzog Encyclopedia of Religious Knowledge. Vol. IV. Draeseke-Goa. Edited by Samuel Macauly Jackson. New York, Funk and Wagnalls Co., r9og. Pp. xvi +500. 